\title{
Terapi Hipotermia Ringan Menurunkan Kadar Protein MMP-9 dan Memperbaiki FOUR Score pada Cedera Otak Traumatik Risiko Tinggi
}

\author{
${ }^{1}$ Hendra, ${ }^{1}$ Halim Wijaya, ${ }^{2}$ Eko Prasetyo, ${ }^{2}$ Maximillian Ch. Oley \\ ${ }^{1}$ Program Studi Ilmu Bedah Fakultas Kedokteran Universitas Sam Ratulangi Manado \\ ${ }^{2}$ KSM Ilmu Bedah Divisi Bedah Bedah Saraf RSUP Prof. Dr. R. D. Kandou Manado \\ Email: bedah.manado@gmail.com
}

\begin{abstract}
In this study, patients with high risk traumatic brain injury (TBI) were treated with mild therapeutic hypothermia and their serum MMP-9 levels as well as neurological outcome were evaluated. This was an experimental analytical study conducted at Intensive Care Unit Prof. Dr. R. D. Kandou Hospital, Manado. The results showed that there were 20 patients with high risk TBI (the FOUR score 57 ) prospective randomly assigned to mild therapeutic hypothermia and control groups. Patients were evaluated at the time of admission and after 72 hours. The serum MMP-9 level was examined by using enzyme-linked immunosorbent assay (ELISA) and the clinical outcome was evaluated by using the FOUR score. Levels of the variables were compared between the two groups. In the hypothermia group, level of serum MMP-9 was decreased $(P>0.05)$ after 72 hours and there was a significant improvement of the FOUR score $(P<0.05)$. Conclusion: Mild therapeutic hypothermia could reduce serum MMP-9 level and significantly improve the neurological outcome after 72 hours.
\end{abstract}

Keyword: mild hypothermia, MMP-9, FOUR score

\begin{abstract}
Abstrak: Penelitian ini dilakukan terhadap penderita cedera otak akibat trauma (COT) risiko tinggi yang diberi perlakuan hipotermia ringan (HPTr) dengan mengevaluasi kadar MMP-9 serum dan hasil klinis yang dinilai melalui skor FOUR. Jenis penelitian ini ialah eksperimental analitik. Penelitian ini dilakukan di Intensive Care Unit (ICU) RSUP Prof. Dr. R. D. Kandou Manado. Terdapat total 20 pasien dengan COT risiko tinggi (skor FOUR $\leq 7$ ) yang secara random dibagi dalam kelompok kontrol dan kelompok HPTr. Pasien dinilai saat masuk dan setelah 72 jam kemudian. Kadar MMP-9 serum dinilai menggunakan enzyme-linked immunosorbent assay (ELISA). Perbedaan level dari kedua variabel ini dibandingkan pada kedua kelompok. Hasil penelitian memperlihatkan bahwa pada kelompok perlakuan HPTr, kadar MMP-9 serum berkurang setelah 72 jam walaupun tidak bermakna $(P>0,05)$ dan terdapat peningkatan skor FOUR secara bermakna $(P<0,05)$. Simpulan: Perlakuan hipotermi ringan dapat menurunkan kadar MMP-9 serum dan memberikan peningkatan hasil klinis melalui penilaian skor FOUR setelah 72 jam kemudian.
\end{abstract}

Kata kunci: hipotermi ringan, MMP-9, FOUR score

Cedera otak akibat trauma (COT) merupakan cedera yang terjadi karena adanya tekanan mekanik eksterna yang mengenai kranium dan komponen intrakranial sehingga menimbulkan kerusakan sementara atau permanen pada otak, gangguan fungsional, atau gangguan psikososial. Angka kejadian dari COT meningkat setiap tahun, terutama karena kecelakaan lalu lintas (KLL) di negara berkembang. Insidennya bervariasi dari 67 -317 per 100.000 individu dan mortalitas sekitar $4-7 \%$ untuk COT sedang dan $50 \%$ untuk COT berat. Di Indonesia, angka kejadian COT risiko tinggi antara 6-12\% dari semua COT dengan angka kematian antara $25-37 \%$. ${ }^{1,2}$

Sejak setengah abad lalu perlakuan 
hipotermia menunjukkan hasil yang memuaskan tetapi aplikasi klinis masih terbatas karena kurangnya pengetahuan tentang patofisiologi, metode kontrol, dan fasilitas. Perlakuan hipotermia dilaporkan pertama kali oleh Fay pada tahun 1938, yang menyatakan bahwa dengan menjaga suhu badan sebesar $27 \%$ memiliki efek mengecilkan tumor dan menurunkan rasa nyeri pada pasien kanker terminal. Pada tahun 1940 Fay juga melakukan hipotermia sebagai strategi terapi untuk penanganan emergensi neurologik pada 124 pasien dengan COT. Keuntungan hipotermia ringan (HPTr) ringan pada penelitian eksperimental dari COT mempunyai efek proteksi kerusakan neuron. ${ }^{3-5}$ Pada tahun 1989, Clifton dan Marion menggunakan hipotermia terapeutik ringan-sedang sebagai tatalaksana COT dan mendapatkan hanya menunjukkan sedikit komplikasi dan hasil yang baik dibandingkan hipoptermia dalam. ${ }^{6}$

Matrix metalloproteinases (MMP) adalah golongan protease netral yang terdegradasi atau modifikasi di hampir semua komponen matriks ekstrasel pada peningkatan permeabilitas sawar darah otak dan patofisiologi dari COT. Inflamasi otak tercetus oleh produksi sitokin proinflamasi, baik jalur intrinsik (mikroglia, astrosit, dan neuron) dan ekstrinsik (infiltrasi makrofag, limfosit, dan leukosit). Peningkatan permeabilitas sawar darah otak (SDO) memungkinkan masuknya molekul plasma dan sel-sel inflamasi ke dalam neuron otak. ${ }^{7}$ Menurut Vilalta dan Sahuquillo, ${ }^{7}$ hasil dua penelitian menyimpulkan bahwa terdapat perubahan kadar MMP darah perifer pada pasien COT.

Penelitian ini bertujuan untuk mendapatkan pengaruh HPTr pada kasus COT risiko tinggi dengan evaluasi berdasarkan skor Full Outline of Unresponsiveness (FOUR) dan kadar MMP-9 serum agar dapat membantu para klinisi dalam menentukan prognosis dan peningkatan mutu penanganan kasus COT risiko tinggi di rumah sakit.

\section{METODE PENELITIAN}

Jenis penelitian ini ialah eksperimental analitik untuk menganalisis pengaruh tindakan hipotermia ringan (HPTr) terhadap penderita COT risiko tinggi dengan dinamika kadar MMP-9 serum yang dapat menyebabkan hasil perbaikan klinis dievaluasi berdasarkan hasil skor FOUR di Intensive Care Unit (ICU) RSUP Prof. Dr. R. D. Kandou Manado, Indonesia. Penelitian dimulai pada bulan November sampai Desember 2016. Sebanyak 20 pasien memenuhi kriteri inklusi dan dibagi atas dua kelompok yaitu dengan dan tanpa HPTr. Pasien diberikan HPTr (suhu 34$36^{\circ} \mathrm{C}$ ) dengan cara pendinginan permukaan. Tindakan HPTr terdiri atas tiga fase yakni: fase induksi, dilakukan 6 jam pasca COT; pemeliharaan/maintenance; dan penghangatan/rewarming $\quad\left(0,5-1^{\circ} \mathrm{C} / \mathrm{jam}\right) \quad$ yang keseluruhannya berlangsung dalam 72 jam. ${ }^{8,9}$ Kadar MMP-9 diukur dengan menggunakan alat terkalibrasi Human MMP-9 Quantikine WLISA kit (catalog no. DMP 900) produksi R\&D System inc. MN, USA. Pengukuran suhu menggunakan alat termometer suhu digital pada rektal. Pemeriksaan dilakukan saat sebelum tindakan HPTr dan setelah 72 jam kemudian.

Data yang diperoleh selanjutnya diolah melalui program SPSS. Pengujian terhadap perbedaan perubahan skala skor FOUR kelompok yang diberikan tindakan HPTr dan kelompok yang tidak diberikan tindakan HPTr digunakan uji Wilcoxon. Demikian pula untuk perbedaan perubahan kadar MMP-9 serum digunakan uji Wilcoxon. Pengujian hubungan antara perubahan kadar MMP-9 serum dengan perubahan skala skor FOUR menggunakan uji Mann Whitney.

\section{HASIL PENELITIAN \\ Karakteristik sampel}

Penelitian ini dilakukan pada bulan September s/d Desember 2016 dan diperoleh subyek penelitian sebanyak 20 orang yang memenuhi kriteria inklusi (Tabel 1). 


\section{Kadar protein MMP-9 serum}

Tabel 2 memperlihatkan pengaruh tindakan HPTr terhadap kadar protein MMP-9 serum pada saat tiba dan 72 jam setelah perlakuan. Terdapat peningkatan kadar MMP-9 yang bermakna $(P<0,05)$ sebesar 98,10 ng/uL dari 455,27 $\pm 74,76$ $\mathrm{pg} / \mathrm{mL}$ menjadi $553,37 \pm 198,87 \mathrm{pg} / \mathrm{mL}$ pada kelompok kontrol, sedangkan pada kelompok penderita yang memperoleh tindakan HPTr terjadi perubahan yang tidak bermakna $(P>$ $0,05)$, namun masih didapatkan kecenderungan kadar protein MMP-9 menurun sebesar $150,59 \mathrm{pg} / \mathrm{mL}$.

\section{Skor FOUR}

Pengaruh HPTr terhadap gambaran perbaikan skor FOUR dapat dilihat pada rangkuman hasil analisis perubahan skor FOUR pada Tabel 3.

Tabel 4 menunjukkan bahwa terjadi peningkatan skor FOUR secara bermakna sebesar 6,0 dari $6,7 \pm 0,5$ menjadi $12,7 \pm 3,1$ pada kelompok HPTr $(P<0,05)$ dan juga pada kelompok kontrol terjadi peningkatan bermakna meskipun hanya sebesar $2,4(P<$ $0,05)$.

Tabel 1. Karakteristik subyek penelitian

\begin{tabular}{lccc}
\hline \multirow{2}{*}{ Karakteristik } & \multicolumn{2}{c}{ Kelompok } & \multirow{P}{*}{$\boldsymbol{P}$} \\
\cline { 2 - 3 } & $\begin{array}{c}\text { Kontrol } \\
(\mathrm{n}=10)\end{array}$ & $\begin{array}{c}\text { HPTr } \\
(\mathrm{n}=10)\end{array}$ & \\
\hline Jenis kelamin (L/P) & $6 / 4$ & $7 / 3$ & 0,500 \\
Usia (tahun); & 29,1 & 29,3 & 0,958 \\
Mean (SD)/Min-Maks & $(8,5) / 20-44$ & $(8,4) / 20-43$ & \\
Onset (menit); & 75,0 & 79,0 & 0,690 \\
Mean(SD)/Min-Maks & $(21,2) / 45-120$ & $(22,8) / 45-120$ & \\
\hline
\end{tabular}

Tabel 2. Pengaruh tindakan HPTr terhadap kadar MMP-9 serum

\begin{tabular}{|c|c|c|c|c|}
\hline \multirow[b]{2}{*}{ Kelompok } & \multicolumn{3}{|c|}{$($ Mean \pm SD) MMP-9 $(\mathrm{pg} / \mathrm{mL})$} & \multirow[b]{2}{*}{$\boldsymbol{P}$} \\
\hline & Saat tiba & Setelah 72 jam & $\Delta$ & \\
\hline Kontrol & $455,27 \pm 74,76$ & $553,37 \pm 198,87$ & 98,10 & 0,037 \\
\hline Hipotermia & $460,57 \pm 62,00$ & $309,98 \pm 226,84$ & $-150,59$ & 0,203 \\
\hline
\end{tabular}

Tabel 3. Pengaruh HPTr terhadap skor FOUR

\begin{tabular}{lcccc}
\hline \multirow{2}{*}{ Kelompok } & \multicolumn{3}{c}{$($ Mean \pm SD) skor FOUR } & \\
\cline { 2 - 4 } & Saat tiba & Setelah 72 jam & $\Delta$ & $\boldsymbol{P}$ \\
\hline Kontrol & $6,7 \pm 0,5$ & $9,1 \pm 2,0$ & 2,4 & 0,005 \\
HPTr & $6,7 \pm 0,5$ & $12,7 \pm 3,1$ & 6,0 & 0,005 \\
\hline
\end{tabular}

Tabel 4. Perbandingan perubahan $(\Delta)$ kadar MMP-9 serum dan skor FOUR antara kedua kelompok

\begin{tabular}{cccc}
\hline \multirow{2}{*}{$\begin{array}{c}\text { Variabel } \\
(\Delta)\end{array}$} & \multicolumn{2}{c}{ Kelompok } & Pontrol \\
\cline { 2 - 3 }$(\mathrm{n}=10)$ & $\begin{array}{c}\mathrm{HPTr} \\
(\mathrm{n}=10)\end{array}$ & \\
\hline $\begin{array}{c}\text { MMP-9 } \\
(\mathrm{pg} / \mathrm{mL})\end{array}$ & 98,10 & $-150,59$ & 0,035 \\
Skor FOUR & 2,4 & 6,0 & 0,011 \\
\hline
\end{tabular}

\section{BAHASAN}

Hasil penelitian menunjukkan bahwa penderita laki-laki lebih banyak daripada perempuan, berusia 20-44 tahun, dan waktu datang (onset) ke rumah sakit 45-120 menit setelah kejadian. Tidak ditemukan 
perbedaan karakteristik yang bermakna $(P>$ $0,05)$ antara kedua kelompok sehingga kedua kelompok dapat dianggap homogen.

Mengenai pengaruh HPTr terhadap kadar MMP-9 serum yaitu pada kelompok kontrol, terjadi peningkatan kadar MMP-9 yang bermakna $(P<0,05)$ sebesar 98,10 $\mathrm{ng} / \mathrm{uL}$ dari $455,27 \pm 74,76 \mathrm{pg} / \mathrm{mL}$ menjadi $553,37 \pm 198,87 \mathrm{pg} / \mathrm{mL}$. Pada kelompok perlakuan HPTr terdapat perubahan yang tidak bermakna $(P>0,05)$, namun masih menunjukkan kecenderungan kadar MMP9 menurun sebesar $150,59 \mathrm{pg} / \mathrm{mL}$ yaitu dari $460,57 \pm 62,00 \mathrm{pg} / \mathrm{mL}$ menjadi $309,98,84 \pm$ $26,84 \mathrm{pg} / \mathrm{mL}$ dan tidak terjadi peningkatan kadar MMP-9 serum seperti halnya pada kelompok kontrol. Penurunan kadar MMP9 serum setelah dilakukan perlakuan HPTr juga diperlihatkan oleh rerata pada grafik Box and Whisker jika dibandingkan dengan rerata pada kelompok kontrol.

Menurut Liu dan Yenari, ${ }^{10}$ efek neuroproteksi yang menguntungkan pada perlakuan HPtr yaitu menurunnya cerebral metabolic rate of oxygen $\left(\mathrm{CMRO}_{2}\right)$, yang berhubungan dengan pasokan glukosa neuron, konsumsi oksigen, dan produksi laktat sehingga HPtr dapat dikatakan menurunkan $\mathrm{CMRO}_{2}$ dan meningkatkan pemakaian glukosa. Konsumsi oksigen otak menurun $5 \%$ setiap penurunan $1{ }^{\circ} \mathrm{C}$ suhu tubuh. Mekanisme neuroprotektif lainnya ialah: 1) preservasi fosfat organik tinggi energi; 2) melambatnya akumulasi asam laktat dan neurotoksin lain; 3) peningkatan pemakaian glukosa; 4) modulasi ekspresi gen; 5) fasilitasi respon anti-inflamasi dan jalur anti-apoptotik; 6) penurunan tekanan intrakranial; 7) stabilisasi sawar darah otak; 8) inhibisi dari produksi radikal bebas; dan 9) penurunan neurotransmiter eksitotoksis seperti glutamat. Neuroproteksi pada HPtr menurunkan produksi radikal bebas dan fasilitasi respon anti-inflamasi yang akan menghambat pembentukan MMP-9.

Pada waktu 3 jam sesudah benturan kadar MMP-9 meningkat dan mencapai maksimal pada 18 jam dan terus bertahan hingga 24 jam. Menurut Kurzepa et al. ${ }^{11}$ peningkatan MMP-9 muncul dalam serum saat destruksi SDO yang disebabkan oleh
MMP-9 tersebut.

Ekspresi MMP 9 pada jaringan otak pada kondisi normal sangat rendah, tetapi ekspresi tersebut akan meningkat saat terjadi iskemi jaringan otak. Pengaturan kadar MMP 9 serum merupakan respon dari cedera otak karena degradasi dari protein matriks ekstrasel. Setelah terjadi iskemi otak, ekspresi yang tidak terkontrol dan aktivitas kadar protein MMP-9 serum menyebabkan proteolisis dan kebocoran SDO hingga kematian sel. ${ }^{12}$ Hasil penelitian Mrozek et al. ${ }^{13}$ melaporkan terdapatnya peningkatan kadar MMP-9 serum pada iskemi maupun perdarahan otak $(149,6 \pm 99 \mathrm{ng} / \mathrm{ml})$, sedangkan pada individu normal ialah $<97 \mathrm{ng} / \mathrm{ml}^{14}$

Hasil keluaran dari COT risiko tinggi ditentukan oleh proses cedera otak sekunder karena 70-90\% COT risiko tinggi disertai cedera otak sekunder dan yang berperan dalam proses tersebut ialah integritas SDO yang dipengaruhi oleh MMP-9 sebagai efektor pada cedera otak sekunder. Protein MMP-9 dapat menjadi penanda biologis bagi penentuan hasil keluaran pada COT risiko tinggi. ${ }^{13}$

Hasil penelitian ini menunjukkan bahwa terjadi peningkatan bermakna dari skor FOUR sebesar 6,0 (dari 6,7 $\pm 0,5$ menjadi 12,7 $\pm 3,1$ ) pada kelompok perlakuan HPTr sedangkan pada kelompok kontrol sebesar 2,4 $(P<0,05)$. Perlakuan HPTr memperbaiki skor FOUR hampir 3 kali lipat dibanding dengan kontrol. Dengan demikian tindakan HPTr terhadap penderita COT risiko tinggi menghasilkan keluaran skor FOUR yang meningkat atau membaik.

Penentuan keluaran penderita COT dilakukan dengan penilaian derajat kesadaran dan biomarker. Penelitian ini dilakukan untuk menentukan keluaran dengan perlakuan HPTr dan diperlukan prediksi menggunakan skor FOUR serta kadar MMP-9 serum. Hasil penelitian ini yang digambarkan dengan grafik Box and Whisker dari perbandingan perubahan ke dua variabel berdasarkan kelompok, membuktikan telah terjadi perubahan semua variabel karena perlakuan HPTr 
dengan perubahan terbesar pada rerata variabel skor FOUR. Hal ini berarti, perlakuan HPTr berpengaruh besar terhadap perubahan klinis.

\section{SIMPULAN}

Dari hasil penelitian ini dapat disimpulkan bahwa perlakuan HPTr dapat menghambat MMP-9 serum pada penderita COT risiko tinggi. Selain itu, perlakuan HPTr menyebabkan perubahan rerata MMP-9 serum dan skor FOUR yang lebih baik pada penderita COT risiko tinggi.

\section{DAFTAR PUSTAKA}

1. Norton JA, Barie PS, Bollinger RR, Chang AE, Lowry S, Mulvihill SJ, et al, editors. Traumatic brain injury. Surgery Basic Science and Clinical Evidence (2nd ed). Springer, 2008; p. 461.

2. Tjahjadi M, Arifin MZ, Singh Gill A, Faried A. Early mortality predictor of severe traumatic brain injury: a single center study of prognostic variables based on admission characteristics. IJNT. 2013:10:3-8.

3. Georgiou AP, Manara AR. Role of therapeutic hypothermia in improving outcome after traumatic brain injury: a systematic review. Br J Anaesth. 2013;110(3):357-67.

4. Hayashi N, Kushi H, Utagawa A, Kinoshita K, Izumi T, Tanjoh K, et al. The clinical issue and effectiveness of brain hypothermia treatment for severly brain-injured patients. In: Hayashi N, editor. Brain Hypothermia. Tokyo: SpringerVerlag, 2000; p. 121-51.

5. Howes D, Gray SH, Brooks SC, Boyd JG, Djogovic D,Golan E, et al. Canadian guidelines for the use of targeted temperature management (therapeutic hypothermia) after cardiac arrest: a joint statement from the Canadian Critical Care Society (CCCS), Canadian Neurocritical Caresociety (CNCCS), and the Canadian Critical Care Trials Group (CCCTG).
Resuscitation. 2016;98:48-63.

6. Hayashi N, Dietrich DW. History of clinical trials of hypothermia treatment of severe brain injury. Brain Hypothermia Treatment. Tokyo: Springer-Verlag, 2004; p. 51-4.

7. Vilalta A, Sahuquillo J, Poca MA, De Los Rios J, Cudrado E, Ortega-Aznar A, et al. Brain contusions induce a strong local overexpression of MMP9. Results of a pilot study. Acta Neurochir Suppl. 2008;102:415-9.

8. Nunnally ME, Jaeschke R, Bellingan GJ, Lacroix J, Mourvillier B, RodriguezVega GM, et al. Targeted temperature management in critical care: a report and recommendations from five professional societies. Crit Care Med. 2011;39(5): 1113-25.

9. Yokobori S, Yokota H. Targeted temperature management in traumatic brain injury. Journal of Intensive Care. 2016;4:28.

10. Liu L, Yenari MA. Therapeutic hypothermia: neuroprotective mechanisms. Front Biosci. 2007;12: 816-25.

11. Kurzepa J, Bielewicz J, Grabarska A, Stelmasiak Z, Stryjecka-Zimmer M, Bartosik-Psujek H. Matrix metalloproteinase- 9 contributes to the increase of Tau protein in serum during acute ischemic stroke. J Clinl Neurosci. 2010;17:997-9.

12. Shigemori $Y$, Katayama $Y$, Mori $T$, Maeda T, Kawamata T. Matrix metalloproteinase-9 is associated with blood-brain barrier opening and brain edema formation after cortical contusion in rats. Acta Neurochir. 2006;96Suppl:130-3.

13. Mrozek S, Dumurgier J, Citerio G, Mebazza A, Geeraerts T. Biomarkers and acute brain injuries: interest and limits. Critical Care. 2014;18:220.

14. Wijdick EFM, Bamlet WR, Marammatom BV, Manno EM, McClelland RL. Validation of a new coma scale: the FOUR score. Ann Neurol. 2005;58:585-93. 